\title{
Public discourses of climate change in Hong Kong
}

\begin{abstract}
:
The changing political environment in Hong Kong is likely to accelerate the transition in environmental policy discourse. Opportunities for critical public involvement are increasing and new environmental discourses are emerging. Yet previous social surveys did not explore the range of these discourses and few focused on climate change. The paper outlines the public discourses of climate change in Hong Kong. Using Q-methodology, four distinctive discourses were identified, namely, Pure Environmentalism, Political Pragmatism, Popular Optimism, and Fair Rationalism. While the first one is climate-centric, the other three are political or social in nature and do not indicate a clear or coherent climate orientation. This suggests that the climate change concern of the Hong Kong public is not tightly embedded into a coherent narrative of social and institutional transformation. Effective climate change governance and policies require strengthening the link between such concern and the public desires for social and institutional transformation. Bringing together the ongoing social movements and environmental campaigns will be instrumental to nurture an active climate citizenry.
\end{abstract}

Keywords: environmental discourse; climate change; public perception; environmental governance; Q-methodology; Hong Kong

Citation:

Lo, A.Y. (in press) Public discourses of climate change in Hong Kong. Journal of Environmental Policy \& Planning. DOI: $\underline{\text { http://dx.doi.org/10.1080/1523908X.2015.1040545 }}$

Publisher version available from the authors: alexloyh@hku.hk 


\section{Introduction}

Hong Kong is situated at the southern seaboard of China and vulnerable to climate change impacts (Environment Bureau, 2010; Fok \& Cheung, 2012; Lam, Hung, \& Fung, 2004). Climate change is inherently a global and regional governance issue, and therefore is not unilaterally manageable for the non-sovereign state of Hong Kong. Since the return of sovereignty from the United Kingdom to the People's Republic of China in 1997, Hong Kong's environmental policies have unwittingly been integrated into China's national and regional policy agendas (Hills, 2004; Hills \& Roberts, 2001; Lee, 2002; Ng, 2012). Despite being an advanced industrialized economy, Hong Kong has failed to demonstrate the political will and institutional capacity to effect policy change for addressing climate change challenges (Francesch-Huidobro, 2012; Ng, 2012). There was no attempt to institute an official climate change strategy until 2010 (Environment Bureau, 2010).

The government's lukewarm response to the issue of climate change is related to the fact that Hong Kong is considered to be a part of China and therefore not obliged to curb greenhouse gases (GHG) (Francesch-Huidobro, 2012). Consequently political actors lack motivation to propose aggressive measures for reducing GHG emissions. Furthermore, climate change and wider environmental problems are generally not considered to be a priority policy issue and have not come to the forefront of public debates within the territory. Public environmental concern is limited to the deterioration of immediate environmental quality (Lee, 2003) and declining over time (Wong and Wan, 2009).

Hong Kong's climate change discourse appears to be lacking agency. Discourse is a shared way of apprehending the world (Dryzek, 2005; Hajer \& Versteeg, 2005; Lo \& Howes, 2015). Although discourse is embedded in language and exists mainly in people's discussion, it can create substantive impacts on political dynamic and policy-making - sustainable development is perhaps the best example (Dryzek, 2005). Historically, Hong Kong's environmental discourse has been dominated by experts and professional managers, but contributions by the private sector are increasingly evident (Hills, 2004).

Over the past decade, however, democratic momentum has arisen not primarily from formal institutions and constitutional arrangements, which are largely dependent on Beijing, but 
local popular debates and social movements emerging from the public sphere (Lam, Lui, \& Wong, 2012; Ma, 2007). Although material influence remains limited due to constitutional constraints, ordinary citizens have become more interested and active in local politics than they were in the colonial era, producing a greater variety of political discourses, both radical and conservative ones. The growing influence of the oppositional civil society extends to controversies over urban and environmental planning (Ng, 2008). The agency of the public can potentially play a critical role in the climate change policy-making process in Hong Kong. Yet, few research studies have attempted to investigate the emerging discourses in the context of climate change.

Although the public discourse of climate change in Hong Kong has rarely been scientifically studied, an Oxfam survey has presented a snapshot of public perception of climate change (Oxfam Hong Kong, 2010). Francesch-Huidobro (2012) and Ng (2012) have also provided useful insights into the institutional aspects of climate change governance in Hong Kong. What remains unclear is the range of public discourses and their socio-political underpinnings. Analyzing the discursive representations of climate change is crucial for understanding the popular basis of new, powerful public discourses that emerge from within the public sphere and indicate a gradual shift in environmental governance paradigm.

The paper presents a systematic analysis of citizens' climate change discourses in Hong Kong. The empirical study characterized different subjective archetypes constructed by ordinary citizens, and was conducted using Q-methodology (Brown, 1980). A particular focus of analysis is the agency represented in each discourse that will potentially be instrumental to driving substantive change in local climate change policy approach. The next section reviews Hong Kong's environmental and climate change discourses. The Q-methodology is then introduced, followed by a description of the survey approach. Results are analyzed and discussed in the ensuing sections.

\section{Hong Kong's Environmental and Climate Change Discourses}

Since the late 1970s, Hong Kong's environmental policies have been deeply entrenched into the paradigm of 'administrative rationalism' (Hills, 2004), which accepts the dominance of the 
administrative state and recognizes the role of experts and professional managers. Administrative rationalism is one of the 'prosaic-reformist' environmental discourses described by John Dryzek (2005). The hallmark of this discourse is the 'command-and-control' approach represented in practice by the extensive use of regulations and penalties. Such 'problem-solving' discourses take the political-economic status quo as given, but in need of adjustment to cope with environmental problems (Dryzek, 2005).

Although administrative rationalism remains a key component of local governance model, structural changes in Hong Kong economy have offered opportunities for a gradual paradigm shift to 'ecological modernization' (Gouldson, Hills, \& Welford, 2008; Hills, 2005; Hills \& Welford, 2002). Ecological modernization is what Dryzek (2005) calls an 'imaginative-reformist' environmental discourse; it refers to a restructuring of the capitalist political economy along more environmental sound lines that recognizes the pivotal role of technological innovation and partnership across different sectors, especially businesses (Christoff, 1996; Hajer, 1995; Howes et al., 2010; Scerri \& Holden, 2013). This policy approach does not compromise market principles, offers business development opportunities, and confirms the importance of the role of the private sector. For these reasons, Hills (2004) argues that ecological modernization, as a weak form of sustainable development, may fit with the prevailing ethos of the pro-growth society of Hong Kong.

However, the processes of policy learning and transition towards an ecologically modernized state have encountered institutional hurdles. Gouldson et al. (2008) contend that in Hong Kong, the entrenched administrative rationalism has precluded policy engagement in the broader social discourse on policy design. Results of a stakeholder analysis have identified different sources of tension impeding the delivery of ecologically modernized policy outcomes (Hills, 2005). One of these factors is the lack of trust among different policy actors, which has undermined the potential for adopting a cross-sectoral cooperative approach (Tsang, Burnett, Hills, \& Welford, 2009; Walker \& Hills, 2014; Wong \& Wan, 2009). The lack of trust in government, in particular, is an enduring reality in Hong Kong and has heightened over the past 15 years due to wider difficulties in democratizing local political institutions and the unsettling democratic debates (Cheng, 2014; Cheung, 2005; Ma, 2007). 
The notable shortfall in political capacity has contributed to failures in institutionalizing and legitimizing climate change policies in Hong Kong (Francesch-Huidobro, 2012). Administrative rationalism is obviously unfit with governing climate change, an environmental problem that does not respect political borders and demands effective coordination across multiple scales (Bulkeley, 2005; Dryzek, 2006). On the other hand, the deteriorating macropolitical environment threatens to erode the prospects for ecological modernization, which requires joint involvement and trusted cooperation between the public, civil society, and the private sector. Hills and associates have surveyed dozens of civil society and business representatives and come to the conclusion that the social and institutional conditions required for ecological modernization have yet to become embedded in Hong Kong (Hills, 2005; Tsang et al., 2009; Walker and Hills, 2014). Little is known, however, about the environmental discourse articulated by the general public in Hong Kong, particularly that of climate change.

As a response to Beijing's unwelcomed but powerful interventions into the local democratic movement, the Hong Kong public has increasingly and more actively engaged in domestic politics (Ma, 2007; Cheng, 2014). Hong Kong people have limited direct influence on shaping politically sensitive policy agendas, but incremental changes in governing practice in the non-sensitive environmental policy domains are foreseeable. For example, the present Under Secretary for the Environment was formerly a pro-democracy, publicly elected legislative councilor (equivalent to Member of Parliament) and chaired an environment-focused think tank prior to joining the government in 2012. Environmental non-governmental organizations (NGOs) in the territory have a long history of dealing with local issues, but have recently embarked on their climate change campaigns with varying successes (Ng, 2012). Although Hong Kong's climate change politics is in a premature stage, the public discourse is emerging.

A social survey commissioned by Oxfam and conducted by a local university has provided mixed evidences (Oxfam Hong Kong, 2010). The vast majority of respondents were aware of climate change and the associated social and health impacts. Yet more than half of them expressed concern and disappointment about the government's capacity for tackling the problem. The high level of climate change awareness is unmatched by the weak motivation to participate in the formulation of climate change policies (Oxfam Hong Kong, 2010). This typical concern- 
action discrepancy has been attributed to the lingering 'trust-deficit' in the wider political economy (Tsang et al., 2009; Wong and Wan, 2009).

Nonetheless, those environmental discourses that represent the views of the majority are not necessarily influential in politics, and vice versa. For example ecological modernization is a dominant discourse promoted by a powerful coalition of actors, typically comprising of business representatives, NGOs, senior government officials, rather than by the mass public. Although climate scepticism is arguably influential, it does not appear attractive to the great majority of citizens in industrialized economies (Leiserowitz, 2005; Lo, 2014; Whitmarsh, 2011) and Hong Kong (Lo \& Jim, in press). To the extent in which the public discourse will ever create impacts on the environmental policy-making process in Hong Kong, it is likely to build upon one that binds itself to the existing political-economic structures, regardless of the number of citizens who support it. Therefore, the relevant research question is: what are the forms of climate change discourse in Hong Kong, and which of them are likely to offer a basis for public influence?

These questions are addressed by findings of a systematic discourse analysis. In keeping with Dryzek’s discourse-analytic framework, the analysis was conducted using Q-methodology (Dryzek, 1990; Dryzek \& Berejikian, 1993; Dryzek \& Niemeyer, 2008). Research methods are described in the following section.

\section{Research Methods}

\section{Q-Methodology}

The history of Q-methodology can be traced back to the 1930s (Brown, 1980; Stephenson, 1953). It is based on statistical factor analysis, but methodologically distinctive and consistent with post-positivist model of scientific inquiry (Durning, 1999). Q-methodology is used to systematically establish patterns of opinions among individuals and elicit the variety of accounts about or around a particular theme or issue (Addams, 2000; McKeown \& Thomas, 1988). It is increasingly seen as a robust technique for investigating the variety of environmental and social perspectives (Brannstrom, 2011; Davies \& Hodge, 2012; Lo, 2013). 
Q-methodology does not produce clusters of individual responses, but delineates idealized, internally coherent structures or forms of viewpoints (Davies \& Hodge, 2012; Dryzek, 1990). These assemblages of viewpoints are presented in the form of statistically generated factors. These factors neither represent individuals nor allow generalization across population; instead, they describe subjective archetypes and can only be generalized across discourses (Dryzek, 1990; Dryzek \& Niemeyer, 2008). An individual may be associated with two or more factors, meaning that a single factor may be only a partial delineation of the individual's viewpoints.

The process of Q study requires respondents to sort a purposively sampled set of stimuli, called Q sample. The Q sample is a set of opinion statements about a particular research topic (e.g. climate change) extracted by the researcher from a constructed 'concourse' (the entire universe of opinions) of statements. Ideally, the source of these statements should be authentic, i.e. originated from the actual conversations or debates within the society about the issue concerned. To reduce the entire population of statements to a manageable number (typically less than 60 to avoid overloading respondents) of statements for Q sorting, the statements are selected by the researcher, preferably based on some random procedures to minimize researcher bias.

Each participant is presented with the Q sample and ranks order them, usually within a forced distribution. The forced distribution approach requires the participant to place the statements into a grid that provides a sorting scale, usually ranging from 'strongly agree' to 'strongly disagree', and permits a finite number of statements to be entered into each agreement/disagreement category, thereby forcing participants to contemplate the statements in a thoughtful way (Webler et al., 2009). The sorting grid used for the presented study is displayed in Figure 1. The rank-ordered distribution of statements is called a ' $Q$ sort', which refers to the entire set of response to all of the listed statements, rather than the response to individual statements.

[FIGURE 1 ABOUT HERE]

Q sorts are factor analyzed. Coherent patterns among the participants are identified by correlating individual Q sorts against one another. This treatment is different from standard $\mathrm{R}$ 
factor analysis in the sense that the individuals (i.e. their Q sorts), rather than their traits or response to individual survey questions, are taken as variables to be correlated. Each identified factor consists of a distinct set of responses and represents categories described similarly by those individuals who are significantly 'loaded' on the same factor. Factor loadings are essentially correlation coefficients, indicating the extent that each Q sort is similar or dissimilar to the composite factor.

Q factors represent idealized, prototype sorts that assemble ideas and opinions sharing among a group of like-minded individuals. Dryzek and Braithwaite (2000, p. 247) suggest that the equivalence between factors and discourses can be established by applying the principles of political discourse analysis in the construction of a sampling frame for selection of statements and soliciting these statements from public debates. The present study adopted essentially the same approach in designing the sampling strategy and in interpreting factors as political discourses (Dryzek, 1990; Dryzek \& Holmes, 2002; Dryzek \& Niemeyer, 2008).

Factor interpretation is based on factor scores. Factor scores for each factor are the scores gained by each Q statement and calculated as a weighted average (usually normalized for direct comparison). The scores of a particular composite factor describe an idealized individual who is completely loaded on that factor and perfectly represents a discourse. The statements are substantially significant relative to the factor; the interpretation of each statement, therefore, is subject to the dynamic of all statements as rank-ordered by the respondents, i.e. self-referent. Examination of significant factors, or typical discourses, is largely an interpretative activity for the researcher. This involves elaboration on the overall patterns and interrelationships of those statements as rank-ordered in the idealized Q sorts that indicate distinct viewpoints and attitudes.

The strength of Q method is that it allows a respondent to assemble a model of their own subjective views, reducing researcher bias and preserving those self-referent factors during statistical analysis (Robbins \& Krueger, 2000), although they are still restricted by the size of Q sample and the range of statements selected for sorting. In $\mathrm{Q}$, each person is not being matched or scored against any outside criterion. Conceptually as well as statistically, Q method treats individual responses to the selected opinion statements always in relation to responses to other statements. Thus the rank-ordering of individual statements and factors should be understood in the context of all other statements and factors, and not read in isolation from others. Moreover, Q 
method can produce robust results using a small sample size. Most Q sorting exercises involve more than 30 respondents, but it is not uncommon to have only 20-30 respondents (Brannstrom, 2011; Lo, 2013), or even fewer (Brown, 1980). Thus, it is not the objective of Q to generalize results across population, but to identify the range of discourses and their qualities.

\section{Survey Instrument}

In this study, representative statements for Q sorting were solicited from multiple sources, including news articles, public speeches, webpages, blogs, scientific articles, book chapters, and transcripts of a climate change policy workshop (Dryzek \& Lo, 2015; Lo, Alexander, Proctor, \& Ryan, 2013). The sampling procedure continued until the pool of statements became saturated, i.e. repeating each other and adding little new information. A total of 264 statements that are directed related to climate change or articulated in a discussion about climate change were identified.

All statements were grouped into a category in accordance with Dryzek's discourseanalytic framework, which has two levels of analysis (Dryzek \& Berejikian, 1993). The primary level consists of four political discourse elements, including basic entities (or ontology), natural relationships, agency, and their motives. The secondary level of analysis applies to the study of people's utterance regarding a political issue. It involves the type of claims that can be made in arguments, including definitive, designative, evaluative and advocative (Dryzek and Berejikian 1993).

This two-dimensional analytical schema was adopted for this study. Although the structured approach could not guarantee a balance of topics about the subject matter (i.e. climate change) to be included in the sample, it was deemed to be useful for creating a Q sample that covers different conceptual elements of political discourses. The only major deviation from Dryzek and Berejikian's (1993) framework is that agency and motives are merged into one category. The three categories were joined by a new one, known as 'capacity for change', which is defined as the ability of an action or a process to make the relationships between entities or actors more natural or unnatural. In practice, this refers to the perception of what precludes a preferred change from occurring or by taking what actions the preferred change would happen. 
The modified analytical schema generated a four-by-four matrix with 16 cells: four political discourse elements crossing with the four categories according to the type of claims. All statements were allotted to one of the 16 cells. Three or four statements were randomly selected from each cell. A small number of them were replaced because of duplication in meaning. Original statements were lightly edited to improve clarity. The final Q sample consists of 54 statements.

\section{Data Collection}

The Q sorting was performed by 50 Hong Kong citizens aged 18 or above. They initially participated in another larger-scale questionnaire survey (Lo and Jim, in press) and, upon completion, were invited to express interest in a follow-up study (i.e. this Q sorting exercise). Of the 800 individuals involved in the larger survey, 219 were interested and voluntarily provided contact details for follow-up.

Participation selection was based on the individual's socio-economic characteristics, notably, gender, age, education level, and income. The research team attempted to recruit a demographically balanced panel of participants equally split into several socio-economic groups (described below). However, many of those contacted were unable to participate because of location and time constraint (the Q sorting exercise took place in a university campus and required 30-60 minutes to complete onsite). The research team managed to fill each socioeconomic group with at least five respondents (i.e. $10 \%$ of the total sample).

The 50 respondents included 27 males and 23 females (see Appendix for details). Fifteen of them were aged 18-24, eighteen aged 25-44, twelve aged 45-64, and five were 65 or older. Twenty-nine of the respondents completed a tertiary degree, fourteen were only educated to high school (grade 10-12), and seven finished at grade 9. Regarding income, fourteen earned less than HKD8,000 per month (HKD/USD = 7.8), ten between HKD8,000 and HKD15,000, five between HKD15,000 and HKD25,000, and nine made more than HKD25,000. Nine were non-income earners and three did not disclose their income. With only 50 individuals involved, the panel cannot be seen as representing the wider population of Hong Kong, which has a total population 
of more than 7 million. Results of Q sorting can only be used to characterize the whole spectrum of discourses, rather than generalizing across the entire population.

The recruitment and data collection processes were undertaken by a university research service provider in Hong Kong appointed by the authors home institution. The Q sample was presented in Chinese. Upon completion of a Q sort, the respondents received HKD200 (approx. USD26) as remuneration. The research was conducted between December 2012 and March 2013.

\section{Results}

The $50 \mathrm{Q}$ sorts were factor analyzed to statistically determine significant patterns or social perspectives. The factor analysis was completed using PQMethod (version 2.32 by Peter Schmolck), a freeware commonly used for Q analysis. Principal Component Analysis (PCA) ${ }^{1}$ and Varimax factor rotation were performed to extract factors. All of the eight factors initially identified yielded an Eigenvalue greater than 1, denoting statistical significance. A four-factor solution was adopted for final analysis because the other four attracted no more than two respondents loading onto them and did not identify a meaningful social perspective (Brannstrom, 2011; Lansing, 2013). The 50 respondents were not evenly distributed among the four factors, and most of them loaded on Factor A. Nonetheless, many of them were highly loaded on more than one factor. This corroborates the common observation that individuals are not bound to one single discourse (Dryzek, 1990) and can be attributed to the composition of the respondent panel which consists of ordinary citizens rather than stakeholders. They are interpreted according to their representative statements and factor scores, and described below as Pure Environmentalism, Political Pragmatism, Popular Optimism, and Fair Rationalism.

\section{Area of Consensus}

\footnotetext{
${ }^{1}$ Both PCA and Centroid Factor Analysis are acceptable methods for Q-analysis, although the latter is advocated by Stephenson (1935) and Brown (1980). PCA is statistically more precise than Centroid and has the advantage of being able to account for the commonality among Q sorts as well as the specificity of individual sorts (Weber et al., 2009).
} 
The four factors identified in this study unanimously dismiss the extremely sceptical view that does not regard global warming, or climate change ${ }^{2}$, as an issue at all (4) (number in brackets refers to the statement number listed in Tables $1-5)$. There is general confidence in climate scientists (47) and the scientific methods for interrogating the issue of climate change (1) (Table 1). Concerted efforts on climate protection by countries at different levels of development are commonly regarded as necessary (37). Consensus is also found in the perception of the relative importance of citizens and politicians (19), but nuanced differences exist when these two groups of actors are individually considered, as the following analysis shows.

\section{[TABLE 1 ABOUT HERE]}

\section{Factor A Pure environmentalism}

Factor A represents pure environmentalism (Table 2). There are 30 (out of 50) defining Q sorts, most of which are produced by the younger and better educated respondents (see Appendix). Those who register to this factor recognize the primacy of the environment and accept the imperative of protecting the endangered environment (39). The strong sense of commitment is matched by a high level of concern about climate change, which is regarded as a serious threat to people's everyday life (33) with catastrophic consequences (30). Yet it is at best only a modest variant of climate alarmism. The pure environmentalists are no fatalists, as they do not believe that it is too late to fix the problem and avoid the impending crisis (43).

\section{[TABLE 2 ABOUT HERE]}

While this factor has deeply engaged with environmental arguments, it holds very few distinctive perspectives about politics and society at large. It stands out from other identified discourses not in terms of their different political or social insights, but precisely the lack of such insights. The pure environmentalists are relatively less interested in the social dimensions of climate change that are related to equity between countries and the exploding population of poor countries $(15,38)$ - not strongly agreeing or disagreeing on these statements as other factors do.

\footnotetext{
${ }^{2}$ In this paper, the term 'climate change' is used interchangeably with 'global warming', although they differ from each other in some aspects (see Whitmarsh, 2009).
} 
Also, they hesitate to decide whether or not new technologies are the most effective solution to climate change (53). The only political consideration is the belief that climate change deniers attack climate science because of political reasons (9).

These mild responses suggest that pure environmentalism is not characterized by a critical political or social intent. Although issues about the society at large fall within the radar of the environmentalists, more discursive energy is devoted to articulating an environmental critique regarding climate change. The primary agency does not come from people, including politicians and citizens, but the degrading environment or the changing climate.

\section{Factor B Political pragmatism}

Individuals are not imprisoned by discourses and ordinary people are often subscribed to more than one discourse (Dryzek, 1990, 2005). Many pure environmentalists are significantly loaded on another factor, particularly 'political pragmatism'. The second factor does not focus on the environment (or the climate) itself; there is only a modest level of concern about the impending environmental crisis $(2,30)$ (Table 3$)$. The discursive emphasis falls upon issues about polity and economy.

\section{[TABLE 3 ABOUT HERE]}

Results indicate a pragmatic position that respects the agency of powerful politicaleconomic entities. In general, politics is not viewed in a negative light. Respondents significantly loaded on this factor are clearly not submitted to the notion that climate change is a conspiracy created to undermine the interests of other countries $(10,11)$. They see prospects for achieving a global consensus on climate change (35), but are less certain about how democratic institutions can help (14) and how individuals can make a difference (40). There is also some concern about punishing those who emit greenhouse gases (44). Perhaps, the solutions lie in strengthening political leadership, because climate change is too overwhelming for ordinary people to manage (22). There is little hostility toward government and politicians $(23,42)$. This factor is identified with the willingness to work within the political domain. 
Viability of green political agency always depends on its ability to perpetuate economic growth (Goodin, 1992). It is then no wonder that the political pragmatism has attracted faith in continuing economic growth and the capitalist economy. The pragmatists are more likely than those highly loaded on other factors to believe that actions for protecting the climate should not sacrifice economic growth $(24,25)$, that businesses can play an important role (7), and that policy success hinges upon the functioning of the market (34). These dispositions are predicated upon a stronger fundamental belief that the right to development is granted (28) and getting rich is glorious (54). Clearly, this factor adheres to the neoliberal and capitalist values that have dominated the Hong Kong society for decades. It is noteworthy that most of the advocates of this discourse were mature individuals (Appendix), suggesting that political pragmatism was favoured by those who have accumulated some experiences in the society.

\section{Factor C Popular Optimism}

Popular optimism holds confidence, if not over-confidence, in the capacity of individuals for dealing with climate change. The 'no troubles' position is associated with a qualified climatesceptical perspective. Popular optimists are relatively more sympathetic to the contested claim that climate change is merely a media story (12) or a hoax (29) (Table 4). They are not impressed by the alarmist statements that environmental crises and catastrophes are impending if people do not act immediately $(2,30)$. Although they accept that climate change, if it is real, will affect people's way of life (33), they categorically reject the view that that it is too late to fix the problem (43).

\section{[TABLE 4 ABOUT HERE]}

The agency of people in driving the required social change is emphasized. Despite the mild climate-sceptical perspective, there is a good deal of optimism about the potential for individuals to make a difference. From the optimist perspective, 'everyone counts', i.e. the people will surely act as long as they see the benefits, and they can deal with the problem effectively without the help of a leader $(5,22)$. Comparing with political pragmatism, popular 
optimism is more sympathetic towards democratic solutions (14), but not necessarily political leadership (22). Without addressing the inevitable tension concerning democratic leadership, this factor has also downplayed tension in other related domains. Popular optimists see no conflicts between maintaining economic growth and taking climate change actions (26, 27), and doubt that these actions will incur high costs (6). Not surprisingly then, they argue that it is possible to lift millions out of poverty at the same time as protecting the planet (41).

In summary, this factor does not identify a pressing problem to worry about and, even if such problem exists, the people will act and can resolve it. While trusting ordinary people, it has not addressed the practical questions about who is going to lead and pay the price, which are all central to the actual climate change debates and negotiations (Giddens, 2009; Ikeme, 2003).

\section{Factor D Fair rationalism}

Factor D denotes fair rationalism and is characterized by a social orientation, instead of an environmental one. It does not intimately engage with the topic of climate change itself beyond expressing concern about its catastrophic effects (30) (Table 5). A careful reading of Tables 2-4 even reveals some incoherence, i.e. not challenging climate scepticism (9) while calling for immediate action (2). This factor does not represent a salient environmental perspective, but socially oriented dispositions. It embodies an emphatic belief that climate change is not driven by the population growth in poor countries (38) and that poor people need not be sacrificed in protecting the environment (41). The well-being of the poor is central to this position.

\section{[TABLE 5 ABOUT HERE]}

Fair rationalism is neither socially idealistic, nor ignorant of practical constraints. Adherents are most strongly critical of radical civic actions (3). They are relatively more aware of the possible high costs of emission mitigation (6) and adhere to the 'polluter pays' principle, i.e. those emitting greenhouse gases should be made liable for the costs incurred (44). While believing that poverty alleviation and environmental protection can co-exist, there is, however, no indication as to how this can be achieved given the expected costs. The rationalists do not 
seek any political or economic solution, but are convinced that new technologies might help tackle climate change (53).

Although this factor is committed to defending the interests of the poor, it explicitly recognizes practical constraints and solutions, and does not accept radicalism, indicating a rational stance. The greater concern about poor people or countries and cost burdens may be related to the fact that this factor was defined mainly by less-educated, mature lower-income earners.

\section{Discussion}

Rather than measuring the strength of climate change concern, this study described different assemblages of climate change perspectives and investigated their socio-political underpinnings. Using Q-methodology, it identified four factors, which can be interpreted as discourses of climate change in Hong Kong. None of them is compatible with the radical forms of climate change scepticism that exist in other advanced industrialized societies (Hulme, 2009; Whitmarsh, 2011).

The first discourse connotes pure environmentalism. It recognizes the climate as the core entity and indicates a sharper sense of environmental commitment. The ecological arguments articulated are moderately alarmist in nature, and are less tightly embedded into the wider public debates and place less emphasis on social and political institutions. This discourse is consistent with a common form of climate change response in Hong Kong. That is, individuals are evidently concerned about climate change, but remain passive in participation and advocacy (Lee, 2003; Oxfam Hong Kong, 2010).

Climate-centric beliefs are less evident in other discourses. One of them is political pragmatism. The discursive architecture of this position is not built upon a serious concern about the changing climate, but on the agency of political leadership and the capitalist economy, which have dominated the political economy in Hong Kong for decades. There is trust in political and capitalist institutions and confidence in their capacity for dealing with climate change. It is believed that any climate policy initiative must respect existing institutional constraints and 
embark within recognized institutions, a form of environmental pragmatism (Lo, 2012; Spash, 2009). It may also be described as an incomplete ecological modernization discourse, which holds a politically and economically pragmatic and non-confrontational stance, yet without indicating clear commitment to technological innovation and a 'no regrets' predisposition (Howes, 2009; Lo, 2008).

Contrary to what Wong and Wan (2009) call 'environmental pessimism' among the majority public, the third discourse represents popular optimism. One of its distinctive features is the greater apathy towards the problem of climate change. More accurately, there is greater confidence in the capacity of individuals to resolving the problem. There is also a higher level of trust in ordinary citizens and democratic institutions and an emphasis on the agency of the people. Apparently this discourse does not embrace administrative rationalism, and it recognizes the most fundamental tenet of ecological modernization, i.e. there is no necessary conflict between economic growth and environmental protection, and embodies the 'strong' dimensions that require democratic and participatory engagement (Christoff, 1996). However, this discourse does not indicate an ecological orientation and seriously address wider institutional issues. There is no clear indication as to how 'the people' could meaningfully influence the climate policy-making process and effect policy change - indeed, they are least likely to see the need to do so.

Fair rationalism is characterized by its social orientation rather than an ecological one. The view that the climate is changing is accepted, but climate change is just not the main theme. This discourse is more strongly influenced by the moral arguments widely accepted in the global south that recognize the pursuit of social equity in environmental protection and the innocence of the poor population with respect to their GHG emissions (Ikeme, 2003). Yet, it is rational in the sense that the price of protecting the climate is explicitly recognized and the role of radical civic action is downplayed. Thus, not only there is no support for climate scepticism, but also a dismissal of climate radicalism, or green radicalism in Dryzek's (2005) terms. This resembles the local grassroot environmental discourse that is oriented to the interests of the poor and amenable to practical considerations (Chan and Hills, 1993), but with a preference for technological solutions.

Comparing the four discourses reveals the different discursive spaces in which climate change concern is situated. Pure environmentalism has no close attachment to a political or 
social discourse. All other discourses are political or social in nature, yet lacking a clear or coherent climate orientation. Political pragmatism recognizes the wider political economy and respects existing systems. Popular optimism embraces participatory democracy and emphasizes the role of the people. Fair rationalism attends to material social interests and rational considerations. The latter two, however, do not clearly indicate how their specific objectives can be achieved under the present political constraints. Popular optimism pursues a bottom-up approach, but the reality in Hong Kong is a bureaucratic preference for a sectoral and technological approach for emission reductions (Francesch-Huidobro, 2012). Fair rationalism opts for a technological approach, but is no more interested in institutionalization and legitimization that are essential to realizing actual governance change (Francesch-Huidobro, 2012).

Political pragmatism indicates richness in political content and a willingness to cooperate with relevant parties. Neither politics nor the economy is seen as an obstacle but a partner to work with in tackling the climate change challenges. This discourse therefore sits most easily within the local political-economic context, in which capital accumulation remains the prevailing ethos and the endeavour for citizen empowerment proves to be an uphill struggle against tight constitutional constraints. Similar to popular optimism and fair rationalism, however, it does not intimately engage with climate change imperatives. Political pragmatism does not accept punishment for emitting GHGs. It also does not endorse the view that protecting the environment needs not sacrifice economic growth, while leaning towards a pro-growth approach. This implies that aggressive emission mitigation measures that would cost the economy are unlikely to be accepted. The environment or the climate does not constitute an agency in this discourse.

In summary, while pure environmentalism has little political and social bearing, the other three discourses do not clearly and coherently articulate a climate change commitment. It is noteworthy that the discourses identified in this paper are not mutually exclusive and many respondents have access to the climate-centric discourse and another discourse. This observation echoes Lee's (2003) findings that the environmental perception of Hong Kong citizens operates at two spatial scales, i.e. the individual/household and the city/metropolitan levels, where they all claim to be personally environmentally aware but unknowingly switch to the other spatial scale when evaluating the apathetic attitude of the wider public. As the Oxfam report has shown 
(Oxfam Hong Kong, 2010), most Hong Kong citizens are concerned about climate change, but the act of action itself and participation in climate change campaigns appear to be a different issue. In other words, the climate change concern of the Hong Kong public is not tightly embedded into a coherent narrative of social and institutional transformation.

This observation indicates a gap between the environmental movements and political economy in Hong Kong. During the 1980s-90s, local environmental campaigns were championed by the middle class and highly educated individuals, and rarely couched in terms of grassroots community interests and attended to the public life of ordinary people (Hills and Chan, 1993). Chiu et al. (1999) have pointed out that the environmental and political movements in Hong Kong were loosely attached to each other. Local environmental NGOs were poorly resourced and lacked capacity for leading costly activities, such as mass mobilization. Moreover, their organizational objectives were oriented to promoting a lifestyle approach at the individual level and advancing a professional management approach in handling policy issues (Chiu et al., 1999). Towards the end of the 1990s, Chiu et al. (1999, p. 86) predicted that "grassroots environmental mobilization will likely be further weakened, and the agenda for the environmental movement will be channelled toward an emphasis on individual life-styles, conservation, and education'. Hong Kong environmentalism was not associated with a critical political ideology.

The critiques of Hills and Chan (1993) Chiu et al. (1999) are still current. While the local political movements have attracted considerable public attention and reached a new height in recent years (Ma, 2007; Cheng, 2014), environmental campaigns have not demonstrated great success in strengthening grassroots support. Climate change appears to be too far away from Hong Kong people's everyday life, and therefore has not been integrated with prevailing political and social imperatives, such as striving for deeper citizen empowerment in policy-making process. The disconnect between wider societal interests and environmental concerns lingered some 20 or 30 years ago. As this paper has revealed, it continues to exist in the domestic debates about climate change. 


\section{Conclusions}

Hong Kong is currently undergoing a major social change that will steer and re-define its political, economic as well as environmental futures. This will accelerate the ongoing transition from the entrenched discourse of administrative rationalism to ecological modernization or another one that is more open and ecologically sustainable. Popular activism might not be found on the climate change front. Political pragmatism, as portrayed in this paper, seems to be more promising in short term, not only because of the pragmatic orientation and compatibility with the prevailing values, but also its lower requirement on deep public engagement, a seemingly essential element of a climate-responsive civil society that neither the existing institutions nor the lay public in Hong Kong are evidently ready for.

Longer-term climate change governance and policies, however, require a creative and collective search for feasible ways for integrating the loosely linked climate change concern of the general public and their earnest desires for social and institutional transformation in other policy domains. Bringing together the ongoing social movements and environmental campaigns will be instrumental to nurture an active climate citizenry. One opportunity is to take advantage of the emerging social activism to rejuvenate local environmentalism. The ongoing social movements are championed by radical student organizations and a critical mass of ordinary young 'netizens', rather than traditional political parties and social organizations (Lee, 2014). As the former group tends to be sympathetic to pro-environmental arguments, a new climate change campaign would benefit from their willingness and ability to draw an actionable link with the successful social movements they currently lead. This will entail a shift away from one that reserved for the middle class and elites to the digital generations and new activists.

The utility of the Q-methodology is demonstrated by highlighting the disconnect between the environmental and the wider social discourses in Hong Kong. With few exceptions (e.g. Lee, 2003), the majority of local studies have focused on the level of environmental awareness and its socioeconomic and psychological determinants. The narrow methodological focus on awareness is based upon the standard assumption that public support to environmental action primarily depends on the strength of environmental belief or attitude. What the Q sorts have revealed, in this case study, is the finite range of climate change discourses and the relationships between their ecological and social underpinnings. By observing the pattern by which statements on 
environmental and social dimensions organized themselves across the four factors, I suggest that the current environmental impasse in Hong Kong may be related to the lack of engagement with the changing social ethos. Since these factors were created by correlating observed Q sorts, my interpretation was based on the systematic relationships between individual subjective positions. The methodology is instrumental to showing the extent to which these discourses are connected to each other and in what terms. This is important for illuminating what need to be done is not only raising public awareness of the environment, but also engaging with other congenial social discourses.

As climate change has risen to political and social pre-eminence, the public debates across the globe have seen bitter struggles and re-negotiations over the terms by which it is governed and managed (Dryzek \& Lo, 2015; Dryzek \& Stevenson, 2011; Kyllönen, 2015). The

contested issues arising from global climate change can no longer be adequately represented by the scientific discourses that emerged in the 1980s and early 1990s, when key international reports, such as the IPCC's First Assessment Report, were released. Capturing and representing the full range of climate change discourses is essential to engaging with the society at large and, ultimately, governing climate change at the global level (Dryzek \& Niemeyer, 2008; Dryzek \& Stevenson, 2011). As this research has shown, however, climate change may not always have a strong and substantive presence in related public discourses and, in some cases, remains a merely peripheral issue in public debates. In societies where climate change is not a politically contested and priority issue, such as Hong Kong, representing discourses is likely to become a challenging task, though necessary.

\section{Acknowledgements}

The author would like to express gratitude to the 50 participants of the Q-survey. This study was funded by the Griffith Climate Change Response Program at Griffith University. Survey fieldwork was undertaken by the Centre for the Advancement of Social Sciences Research of the Hong Kong Baptist University. 


\section{References:}

Addams, Helen. (2000). Q Methodology. In H. Addams \& J. Proops (Eds.), Social discourse and environmental policy : an application of $Q$ methodology. Cheltenham; Northampton, Mass.: Edward Elgar.

Brannstrom, Christian. (2011). A Q-Method Analysis of Environmental Governance Discourses in Brazil's Northeastern Soy Frontier. The Professional Geographer, 63(4), 531-549. doi: 10.1080/00330124.2011.585081

Brown, S. R. (1980). Political Subjectivity. New Haven: Yale University Press.

Bulkeley, Harriet. (2005). Reconfiguring environmental governance: Towards a politics of scales and networks. Political Geography, 24(8), 875-902. doi: http://dx.doi.org/10.1016/j.polgeo.2005.07.002

Cheng, Joseph Yu Shek. (2014). The Emergence of Radical Politics in Hong Kong: Causes and Impact. China Review, 14(1), 199-232. doi: 10.2307/23723007

Cheung, Anthony B. L. (2005). Hong Kong's post-1997 institutional crisis: problems of governance and institutional incompatibility. Journal of East Asian Studies, 5, 135-167.

Christoff, Peter. (1996). Ecological modernization, ecological modernities. Environmental Politics, 5(3), 476-500.

Davies, Ben B., \& Hodge, lan D. (2012). Shifting environmental perspectives in agriculture: Repeated Q analysis and the stability of preference structures. Ecological Economics, 83(0), 51-57. doi: http://dx.doi.org/10.1016/i.ecolecon.2012.08.013

Dryzek, John S. (1990). Discursive Democracy: Politics, Policy, and Political Science. Cambridge: Cambridge University Press.

Dryzek, John S. (2005). The Politics of the Earth: Environmental Discourses (2nd ed.). New York: Oxford University Press.

Dryzek, John S. (2006). Deliberative Global Politics: Discourse and Democracy in a Divided World Cambridge: Polity.

Dryzek, John S., \& Berejikian, Jefferey. (1993). Reconstructive democratic theory. American Political Science Review, 87(1), 48-60.

Dryzek, John S., \& Braithwaite, Valerie. (2000). On the Prospects for Democratic Deliberation: Values Analysis Applied to AustralianPolitics. Political Psychology, 21(2), 241-266. doi: 10.1111/0162895X.00186

Dryzek, John S., \& Holmes, Leslie. (2002). Post-Communist Democratization: Political Discourses Across Thirteen Countries. Cambridge: Cambridge University Press.

Dryzek, John S., \& Lo, Alex Y. (2015). Reason and rhetoric in climate communication. Environmental Politics, 24(1), 1-16.

Dryzek, John S., \& Niemeyer, Simon. (2008). Discursive representation. American Political Science Review, 102(4), 481-493.

Dryzek, John S., \& Stevenson, Hayley. (2011). Global democracy and earth system governance. Ecological Economics, 70(11), 1865-1874.

Durning, Dan. (1999). The transition from traditional to postpositivist policy analysis: A role for Qmethodology. Journal of Policy Analysis and Management, 18(3), 389-410.

Environment Bureau. (2010). Hong Kong's climate Change strategy and action agenda: Consultation document. Hong Kong: Environmental Protection Department.

Fok, Lincoln, \& Cheung, Lewis T. O. (2012). Evaluating the impact reduction strategies for the tropical cyclone hazard in Hong Kong. Asian Geographer, 29(2), 121-129. doi: $10.1080 / 10225706.2012 .742617$ 
Francesch-Huidobro, Maria. (2012). Institutional deficit and lack of legitimacy: the challenges of climate change governance in Hong Kong. Environmental Politics, 21(5), 791-810. doi: 10.1080/09644016.2012.686221

Giddens, Anthony. (2009). The politics of climate change. Cambridge, UK: Polity.

Goodin, Robert E. (1992). Green Political Theory. Cambridge: Polity.

Gouldson, Andrew, Hills, Peter, \& Welford, Richard. (2008). Ecological modernisation and policy learning in Hong Kong. Geoforum, 39, 319-330.

Hajer, Maarten A. (1995). The politics of environmental discourse ecological modernization and the policy process. New York : : Oxford University Press.

Hajer, Maarten A., \& Versteeg, Wytske. (2005). A decade of discourse analysis of environmental politics: Achievements, challenges, perspectives. Journal of Environmental Policy \& Planning, 7(3), 175184. doi: $10.1080 / 15239080500339646$

Hills, Peter R. (2004). Administrative rationalism, sustainable development and the politics of environmental discourse in Hong Kong. In T. Mottershead (Ed.), Sustainable Development in Hong Kong. Hong Kong: Hong Kong University Press.

Hills, Peter R. (2005). Environmental reform, ecological modernization and the policy process in Hong Kong: an exploratory study of stakeholder perspectives. Journal of Environmental Planning and Management, 48(2), 209-240.

Hills, Peter R., \& Roberts, Peter. (2001). Political integration, transboundary pollution and sustainability: challenges for environmental policy in the Pearl River Delta Region. Journal of Environmental Planning and Management, 44(4), 455-473.

Hills, Peter R., \& Welford, Richard. (2002). Ecological modernisation as a weak form of sustainable development in Hong Kong. International Journal of Sustainable Development and World Ecology, 9, 315-331.

Howes, Michael. (2009). A Climate of Change: Ecological modernisation and the politics of carbon trading in Australia. Paper presented at the Paper for the Australasian Political Studies Association Conference, Macquarie University: Sydney.

Howes, Michael, McKenzie, Marteena, Gleeson, Bredan, Gray, Rowan, Byrne, Jason, \& Daniels, Peter. (2010). Adapting ecological modernisation to the Australian context. Journal of Integrative Environmental Sciences, 7(1), 5-21.

Hulme, Mike. (2009). Why We Disagree About Climate Change. Cambridge: Cambridge University Press.

Ikeme, Jekwu. (2003). Equity, environmental justice and sustainability: Incomplete approachesin climate change politics. Global Environmental Change, 13, 195-206.

Kyllönen, Simo. (2015). Civil Disobedience, Climate Protests and a Rawlsian Argument for 'Atmospheric' Fairness. Environmental Values 23(5), 593-613.

Lam, Ka Se, Hung, Wing Tat, \& Fung, Wing Yee. (2004). Characterizing the Climate Change Impact in Hong Kong. Final report submitted to the HKSAR - Environmental Protection Department. Hong Kong: Department of Civil \& Structural Engineering, The Hong Kong Polytechnic University.

Lam, Wai-man, Lui, Percy Luen-tim, \& Wong, Wilson. (2012). Contemporary Hong Kong Government and Politics: Expanded Second Edition (Vol. 2): Hong Kong University Press.

Lansing, David M. (2013). Not all baselines are created equal: A Q methodology analysis of stakeholder perspectives of additionality in a carbon forestry offset project in Costa Rica. Global Environmental Change, 23(3), 654-663. doi: http://dx.doi.org/10.1016/j.gloenvcha.2013.02.005

Lee, Francis L. F. (2014). Internet, citizen self-mobilisation, and social movement organisations in environmental collective action campaigns: two Hong Kong cases. Environmental Politics, 1-18. doi: 10.1080/09644016.2014.919749

Lee, Yok Shiu F. (2002). Tackling Cross-border Environmental Problems in Hong Kong: Initial Responses and Institutional Constraints. The China Quarterly, 172, 986-1009. 
Lee, Yok Shiu F. (2003). Environmental consciousness in Hong Kong. Southeast Asian Studies, 41(1), 1535.

Leiserowitz, Anthony A. (2005). American Risk Perceptions: Is Climate Change Dangerous? Risk Analysis, 25(6), 1433-1442.

Lo, Alex Y, \& Howes, Michael. (2015). Power and Carbon Sovereignty of a Non-Traditional Capitalist State: The Carbon Trading Discourse of China. Global Environmental Politics, 15(1), 60-82.

Lo, Alex Y. (2008). Merging electricity and environment politics of Hong Kong: identifying the barriers from the ways that sustainability is defined. Energy Policy, 36(4), 1521-1537.

Lo, Alex Y. (2012). The encroachment of value pragmatism on pluralism: The practice of the valuation of urban green space using stated-preference approaches. International Journal of Urban and Regional Research, 36(1), 121-135.

Lo, Alex Y. (2013). Agreeing to pay under value disagreement: Reconceptualizing preference transformation in terms of pluralism with evidence from small-group deliberations on climate change. Ecological Economics, 87, 84-94.

Lo, Alex Y. (2014). The right to doubt: climate-change scepticism and asserted rights to private property. Environmental Politics 23(4), 549-569.

Lo, Alex Y., Alexander, Kim S., Proctor, Wendy, \& Ryan, Anthony. (2013). Reciprocity as deliberative capacity: Lessons from a citizens deliberation on carbon pricing mechanisms in Australia. Environment and Planning C: Government \& Policy, 31(3), 444-459.

Lo, Alex Y., \& Jim, C. Y. (in press). Come rain or shine? Public expectation on local weather change and differential effects on climate change attitude. Public Understanding of Science, DOI: 10.1177/0963662513517483.

Ma, Ngok. (2007). Political development in Hong Kong: state, political society, and civil society. Hong Kong: Hong Kong University Press.

McKeown, Bruce, \& Thomas, Dan. (1988). Q Methodology. Newbury Park, CA.: Sage Publications.

$\mathrm{Ng}$, Mee Kam. (2008). From Government to Governance? Politics of Planning in the First Decade of the Hong Kong Special Administrative Region. Planning Theory \& Practice, 9(2), 165-185.

$\mathrm{Ng}$, Mee Kam. (2012). A critical review of Hong Kong's proposed climate change strategy and action agenda. Cities, 29(2), 88-98. doi: http://dx.doi.org/10.1016/i.cities.2011.08.001

Oxfam Hong Kong. (2010). Hong Kong's Vulnerability to Global Climate Change Impacts: An Oxfam Report on 2010 Public Survey and Policy Recommendations. Hong Kong: Oxfam Hong Kong.

Robbins, Paul, \& Krueger, Rob. (2000). Beyond bias? The promise and limits of $Q$ method in human geography. Professional Geographer, 52(4), 636-648.

Scerri, Andy, \& Holden, Meg. (2013). Ecological Modernization or Sustainable Development? Vancouver's Greenest City Action Plan: The City as 'manager' of Ecological Restructuring. Journal of Environmental Policy \& Planning, 1-19. doi: 10.1080/1523908X.2013.836962

Spash, Clive L. (2009). Editorial: The new environmental pragmatists, pluralism and sustainability. Environmental Values, 18, 253-256.

Stephenson, William. (1953). The Study of Behavior: Q Technique and Its Methodology. Chicago: University of Chicago Press.

Tsang, Stephen, Burnett, Margarett, Hills, Peter, \& Welford, Richard. (2009). Trust, public participation and environmental governance in Hong Kong. Environmental Policy and Governance, 19(2), 99114. doi: 10.1002/eet.502

Walker, Richard M., \& Hills, Peter. (2014). Changing dimensions of trust in government: An exploration in environmental policy in Hong Kong. Public Administration and Development, 34(2), 123-136. doi: 10.1002/pad.1677

Webler, Thomas, Danielson, S, \& Tuler, S. . (2009). Using Q method to reveal social perspectives in environmental research. Greenfield MA: Social and Environmental Research Institute. 
Whitmarsh, Lorraine. (2009). What's in a name? Commonalities and differences in public understanding of "climate change" and "global warming". Public Understanding of Science, 18, 401-420.

Whitmarsh, Lorraine. (2011). Scepticism and uncertainty about climate change: Dimensions, determinants and change over time. Global Environmental Change, 21(2), 690-700.

Wong, Timothy Ka-Ying, \& Wan, Po-San. (2009). Lingering environmental pessimism and the role of government in Hong Kong. Public Administration and Development, 29(5), 441-451. doi: 10.1002/pad.530 
Table 1 Consensus statements of the four factors

\begin{tabular}{cllccc}
\multirow{2}{*}{ No. Statement } & \multicolumn{3}{c}{ Factor scores } \\
\cline { 3 - 6 } & & A & B & C & D \\
\hline 1 & We should be scientific and rational in dealing with the issue of climate & 3 & 3 & 3 & 5 \\
& change & & & \\
4 & Global warming, so what? I don't care. Let it change! & -4 & -3 & -4 & -4 \\
19 & I have faith in people, not politicians \\
37 & $\begin{array}{l}\text { The efforts of developing countries alone are not sufficient to tackle } \\
\text { climate change }\end{array}$ & 0 & -1 & 1 & 0 \\
47 & Scientists have no evidence that CO2 will overheat the planet & 4 & 3 & 2 \\
\hline
\end{tabular}


Table 2 Distinguishing statements of pure environmentalism (Factor A)

\begin{tabular}{clcccc}
\multirow{2}{*}{ No. Statement } & \multicolumn{3}{c}{ Factor scores } \\
\cline { 3 - 6 } & & A & B & C & D \\
\hline 9 & Some people are politically motivated to nitpick about climate science & $\mathbf{2 *}$ & 0 & -1 & -3 \\
15 & We can achieve sustainability only if we pursue far greater social equity & $\mathbf{2}$ & $\mathbf{3}$ & $\mathbf{4}$ & 4 \\
& between countries & & & & \\
30 & Global warming will have catastrophic effects & $\mathbf{5 *}$ & $\mathbf{1}$ & -1 & 3 \\
33 & Climate change threatens our way of life & $\mathbf{3}$ & 0 & 3 & 1 \\
38 & Climate change is driven by the population growth in poor countries & $\mathbf{- 2}$ & -3 & -3 & -5 \\
39 & We're not here to serve the earth & $\mathbf{- 3 *}$ & 0 & 1 & -1 \\
43 & It's too late; we can no longer halt the impacts of climate change & $\mathbf{- 4 *}$ & -1 & -5 & 0 \\
53 & Climate change are best tackled by fostering new energy technologies & $\mathbf{0 *}$ & $\mathbf{1}$ & $\mathbf{2}$ & 4 \\
\hline
\end{tabular}

All statements are significant at .05 level. * denotes significance at .01 level 
Table 3 Distinguishing statements of political pragmatism (Factor B)

\begin{tabular}{|c|c|c|c|c|c|}
\hline \multirow{2}{*}{ No. } & \multirow{2}{*}{ Statement } & \multicolumn{4}{|c|}{ Factor scores } \\
\hline & & $A$ & B & $\mathrm{C}$ & $D$ \\
\hline 2 & There will be an environmental crisis if we don't act urgently & 4 & $1 *$ & 0 & 3 \\
\hline 7 & $\begin{array}{l}\text { It is unrealistic to expect that business will achieve all that is required for } \\
\text { global sustainability }\end{array}$ & 1 & -1 & 1 & 2 \\
\hline 10 & $\begin{array}{l}\text { Climate change is a conspiracy created by developed countries in an } \\
\text { attempt to stop emerging economies from growing }\end{array}$ & -1 & -3 & -2 & -1 \\
\hline 11 & $\begin{array}{l}\text { The whole climate change issue is a left-wing conspiracy to deindustrialise } \\
\text { the western world }\end{array}$ & -2 & $-5 *$ & -2 & -1 \\
\hline 14 & $\begin{array}{l}\text { Democracy works best on short-term issues, so long-term climate change } \\
\text { is a real challenge }\end{array}$ & 0 & 1 & -2 & 0 \\
\hline 22 & $\begin{array}{l}\text { Ordinary people are not in a position to deal with climate change. We } \\
\text { need a leader }\end{array}$ & 0 & 2 & -2 & 1 \\
\hline 23 & Politicians are only talking because they want the vote & 1 & 0 & 2 & 2 \\
\hline 24 & $\begin{array}{l}\text { We should tackle the problem of climate change, but our economy must } \\
\text { keep growing }\end{array}$ & -1 & $2 *$ & -1 & 0 \\
\hline 25 & We're not going to save the planet by putting our country out of business & -3 & $0 *$ & -3 & -2 \\
\hline 28 & We have a right to develop our economy & 0 & 3* & 0 & 1 \\
\hline 30 & Global warming will have catastrophic effects & 5 & $1 *$ & -1 & 3 \\
\hline 34 & For any policy to succeed, it must work with the market, not against it & 1 & 2 & 1 & 1 \\
\hline 35 & $\begin{array}{l}\text { I believe citizens from all nations can come to a consensus about climate } \\
\text { change }\end{array}$ & -1 & 3* & 0 & 0 \\
\hline 40 & Everyone can make a difference in dealing with climate change & 4 & $2 *$ & 4 & 5 \\
\hline 42 & Governments try to use climate change to hold onto power & 0 & -2 & -1 & 0 \\
\hline 44 & There must be a punishment for those emitting greenhouse gases & 1 & -1 & 0 & 3 \\
\hline 54 & Getting rich is glorious & -1 & $1 *$ & -1 & -2 \\
\hline
\end{tabular}

All statements are significant at .05 level. ${ }^{*}$ denotes significance at .01 level 
Table 4 Distinguishing statements of popular optimism (Factor C)

\begin{tabular}{|c|c|c|c|c|c|}
\hline \multirow{2}{*}{ No. } & \multirow{2}{*}{ Statement } & \multicolumn{4}{|c|}{ Factor scores } \\
\hline & & A & $\mathrm{B}$ & $\mathbf{C}$ & $\mathrm{D}$ \\
\hline 2 & There will be an environmental crisis if we don't act urgently & 4 & 1 & 0* & 3 \\
\hline 5 & $\begin{array}{l}\text { People are keen to make environmental changes if they could be sure } \\
\text { there would be benefits }\end{array}$ & 2 & 4 & 5 & 2 \\
\hline 6 & Costs of emission mitigation are too high relative to the benefits & -1 & -1 & $-3 *$ & 1 \\
\hline 12 & Global warming isn't caused by people, but manufactured by the media & -3 & -3 & $0 *$ & -4 \\
\hline 14 & $\begin{array}{l}\text { Democracy works best on short-term issues, so long-term climate change } \\
\text { is a real challenge }\end{array}$ & 0 & 1 & -2 & 0 \\
\hline 22 & $\begin{array}{l}\text { Ordinary people are not in a position to deal with climate change. We } \\
\text { need a leader }\end{array}$ & 0 & 2 & -2 & 1 \\
\hline 26 & Climate change actions are out to strangle economic growth & -2 & -2 & -4 & -3 \\
\hline 27 & Economic growth need not sacrifice the environment & 1 & 0 & $3 *$ & -1 \\
\hline 29 & Global warming is a hoax & -5 & -5 & $-1 *$ & -3 \\
\hline 30 & Global warming will have catastrophic effects & 5 & 1 & $-1 *$ & 3 \\
\hline 33 & Climate change threatens our way of life & 3 & 0 & 3 & 1 \\
\hline 41 & $\begin{array}{l}\text { It is possible to lift millions out of poverty at the same time as protecting } \\
\text { the planet }\end{array}$ & -1 & -2 & 3 & 4 \\
\hline 43 & It's too late; we can no longer halt the impacts of climate change & -4 & -1 & $-5 *$ & 0 \\
\hline
\end{tabular}

All statements are significant at .05 level. * denotes significance at .01 level 
Table 5 Distinguishing statements of fair rationalism (Factor D)

\begin{tabular}{clcccc}
\multirow{2}{*}{ No. Statement } & \multicolumn{3}{c}{ Factor scores } \\
\cline { 3 - 6 } & A & B & C & D \\
\hline 3 & It is necessary to use street protests and borderline violent methods to & -2 & -3 & -2 & $-5^{*}$ \\
& make our point & & & & \\
6 & Costs of emission mitigation are too high relative to the benefits & -1 & -1 & -3 & $\mathbf{1}^{*}$ \\
30 & Global warming will have catastrophic effects & 5 & 1 & -1 & $\mathbf{3}^{*}$ \\
38 & Climate change is driven by the population growth in poor countries & -2 & -3 & -3 & $-5^{*}$ \\
41 & $\begin{array}{l}\text { It is possible to lift millions out of poverty at the same time as protecting } \\
\text { the planet }\end{array}$ & -1 & -2 & 3 & $\mathbf{4}$ \\
44 & There must be a punishment for those emitting greenhouse gases & 1 & -1 & 0 & $\mathbf{3}^{*}$ \\
53 & Climate change are best tackled by fostering new energy technologies & 0 & 1 & 2 & $\mathbf{4}$ \\
\hline
\end{tabular}

All statements are significant at .05 level. * denotes significance at .01 level 
